\title{
DIVERSITY PATTERNS OF NOTOSUCHIA (CROCODYLIFORMES, MESOEUCROCODYLIA) DURING THE CRETACEOUS OF GONDWANA
}

DIEGO POL ${ }^{1}$

JUAN MARTIN LEARDI'

${ }^{1}$ CONICET. Museo Paleontológico Egidio Feruglio, Av. Fontana 140, U9100GYO Trelew, Chubut, Argentina.

${ }^{2}$ IDEAN, Departamento de Ciencias Geológicas, Universidad de Buenos Aires, Ciudad Universitaria Pab. II, C1428EHA Ciudad Autónoma de Buenos Aires, Argentina.

Recibido: 10 de Junio de 2015 - Aceptado: 21 de Noviembre de 2015

Para citar este artículo: Diego Pol, and Juan Martin Leardi (2015). Diversity patterns of Notosuchia (Crocodyliformes, Mesoeucrocodylia) during the Cretaceous of Gondwana. En: M. Fernández y Y. Herrera (Eds.) Reptiles Extintos - Volumen en Homenaje a Zulma Gasparini. Publicación Electrónica de la Asociación Paleontológica Argentina 15(1): 172-186.

Link a este artículo: http://dx.doi.org/10.5710/PEAPA.10.06.2015.108

DESPLAZARSE HACIA ABAJO PARA ACCEDER AL ARTÍCULO

Asociación Paleontológica Argentina Maipú $6451^{\circ}$ piso, C1006ACG, Buenos Aires República Argentina

Tel/Fax (54-11) 4326-7563 Web: www.apaleontologica.org.ar

Otros artículos en Publicación Electrónica de la APA 15(1):

\section{de la Fuente \& Sterli}

ESTADO DEL CONOCIMIENTO DE LAS TORTUGAS EXTINTAS DEL TERRITORIO ARGENTINO: UNA PERSPECTIVA HISTÓRICA.

\section{Paulina Carabajal}

GUIA PARA EL ESTUDIO DE LA NEUROANATOMÍA DE DINOSAURIOS SAURISCHIA, CON ENFASIS EN FORMAS SUDAMERICANAS.
Bardet \& Galoyer

THE LOST WORLD OF GEORGES CUVIER: MOSASAURIDS FROM THE CAMPANIAN MEUDON CHALK (FRANCE). 


\title{
DIVERSITY PATTERNS OF NOTOSUCHIA (CROCODYLIFORMES, MESOEUCROCODYLIA) DURING THE CRETACEOUS OF GONDWANA
}

\author{
DIEGO POL ${ }^{1}$ AND JUAN MARTIN LEARDI²
}

${ }^{1}$ CONICET. Museo Paleontológico Egidio Feruglio, Av. Fontana 140, U9100GYO Trelew, Chubut, Argentina.dpol@mef.org.ar

2IDEAN, Departamento de Ciencias Geológicas, Universidad de Buenos Aires, Ciudad Universitaria Pab. II, C1428EHA Ciudad Autónoma de Buenos Aires, Argentina. jmleardi@gl.fcen.uba.ar

\begin{abstract}
Notosuchia is a diverse clade of Crocodyliformes that achieved a remarkable diversity during the Cretaceous. This group is particularly abundant in continental deposits of Gondwana throughout the Cretaceous, especially in South America. Notosuchia was first recognized as a distinct group by the early work of Gasparini in the 1970's and in the last decades numerous discoveries and studies have increased the geographical, temporal and taxonomical scope of this clade. Here we analyze the patterns of diversity of Notosuchia during the Cretaceous, considering their taxic and phylogenetic diversity, as well as implementing sampling corrections aiming to account for the uneven fossil record of different stages of the Cretaceous. We identify two subsequent pulses of diversification in the late Early Cretaceous and the middle Late Cretaceous, followed by two separate extinction events that occurred during the latest Cretaceous (Campanian/Maastrichtian). We discuss the contribution of the South American, African, and Malagasy fossil records to the diversity curves, which indicates the African fossil record dominates the first pulse of diversification and the South American fossil record exclusively compose the second pulse of diversification. Finally, we analyze the patterns of diversity shown by the different subclades of Notosuchia throughout the Cretaceous, which reveal markedly different evolutionary dynamics of four major groups of notosuchian crocodyliforms.
\end{abstract}

Key words. Notosuchia. Diversity. Radiation. Cretaceous. Gondwana.

Resumen. PATRONES DE DIVERSIDAD DE NOTOSUCHIA (CROCODYLIFORMES, MESOEUCROCODYLIA) DURANTE EL CRETÁCICO DE GONDWANA. Notosuchia es un clado diverso de Crocodyliformes que adquirió una notable diversidad durante el Cretácico. Este grupo es particularmente abundante en depósitos continentales de Gondwana a lo largo del Cretácico, especialmente en América del Sur. Notosuchia fue originalmente reconocido como un grupo distintivo por Gasparini en trabajos durante la década de 1970 y en años recientes numerosos estudios y descubrimientos han incrementado el rango geográfico, temporal y taxonómico de este clado. En este trabajo analizamos los patrones de diversidad de Notosuchia durante el Cretácico, considerando su diversidad taxonómica y filogenética, así como también implementando correcciones de muestreo que intentan considerar el dispar registro fósil de los diferentes pisos del Cretácico. Se identifican dos pulsos sucesivos de diversificación en el Cretácico Temprano tardío y en el Cretácico Tardío medio, seguidos de dos eventos separados de extinción ocurridos durante el Cretácico más tardío (Campaniense/Maastrichtiense). Se discuten las contribuciones del registro fósil de América del Sur, África, y Madagascar a las curvas de diversidad, las cuales indican que el registro africano domina el primer pulso de diversificación y el registro sudamericano compone de manera exclusiva el segundo pulso de diversificación. Finalmente, analizamos los patrones de diversidad de los diferentes subclados de Notosuchia a través del Cretácico, los cuales revelan una dinámica evolutiva marcadamente diferente para cuatro grandes grupos de crocodyliformes notosuquios.

Palabras clave. Notosuchia. Diversidad. Radiación. Cretácico. Gondwana.

Notosuchia is the most diverse clade of Gondwanan crocodyliforms that thrived during the Cretaceous Period (Turner and Sertich, 2010; Pol et al., 2014). Much of the currently known diversity, including over 70 different species, has been revealed during the last 25 years through discoveries across most Gondwanan landmasses. The bulk of this di- versity is found in South America, where notosuchian remains have been known since the latest XIXth century. The description of Notosuchus terrestris and Cynodonthosuchus rothi from the Late Cretaceous of Patagonia (Woodward, 1896) was the first contribution to notosuchian diversity in South America. Subsequently, during the first half of the 
$X X^{\text {th }}$ century the discoveries of Uruguaysuchus (Rusconi, 1933) and five taxa from the Cretaceous of Brazil (Price, 1945, 1950a,b, 1955, 1959) increased the diversity of the group currently known as Notosuchia. The Brazilian taxa described by Price included small-bodied forms known from relatively complete remains (i.e., Araripesuchus; Price, 1959), large-bodied taxa with adaptations to hypercarnivory (i.e., Baurusuchus; Price, 1945), and more fragmentary specimens with unusual tooth morphology (i.e., Sphagesaurus, Itasuchus, Peirosaurus; Price, 1950a,b, 1955).

The systematic arrangement of these Cretaceous crocodyliforms from South America was tackled in a series of influential papers by Gasparini (1971, 1972, 1981, 1982), who recognized and created different taxonomic groups for classifying these forms. One of the most relevant contributions was the creation of Notosuchia (Gasparini, 1971), a high level group that clustered small-bodied forms such as Notosuchus, Araripesuchus, and Uruguaysuchus. Within Notosuchia, Gasparini (1971) restricted Notosuchidae to Notosuchus and grouped the latter two genera by erecting the family Uruguaysuchidae. Other contributions of Gasparini were focused on less diverse groups at that time, such as Sebecosuchia (Gasparini, 1972) and Peirosauridae (Gasparini, 1982), which were not considered part of Notosuchia until recently (Ortega et al., 2000; Pol, 2003; Turner and Sertich, 2010; Pol and Powell, 2011; Pol et al., 2012, 2014). Within Sebecosuchia, Gasparini validated the Cretaceous group Baurusuchidae (including Baurusuchus and the fragmentary
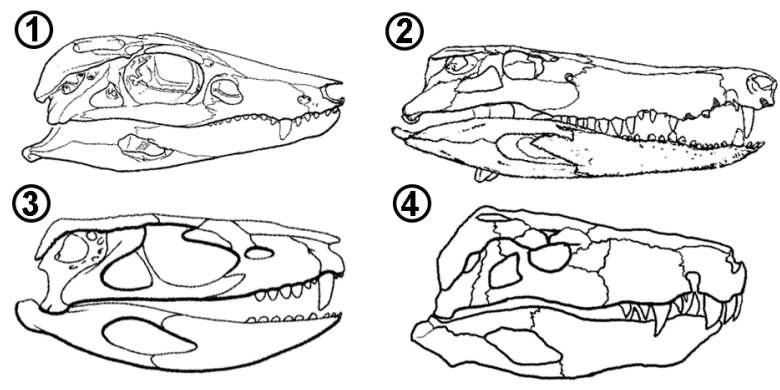

Figure 1. Skull reconstruction of four groups of Cretaceous notosuchians. 1, Uruguaysuchidae (Araripesuchus gomesii); 2, Peirosauridae (Hamadasuchus reboulii); 3, Notosuchidae (Notosuchus terrestris); 4, Baurusuchidae (Baurusuchus salgadoensis). Modified from Pol and Larsson (2011). (ynodontosuchus) as related to the Cenozoic sebecids. Finally, Gasparini erected Peirosauridae (Gasparini, 1982) by recognizing the distinctness of Peirosaurus torminni from all other crocodyliforms, while studying the type materials of this taxon described originally by Price (1955), and more complete material discovered in Patagonia. These studies therefore organized the known diversity of Cretaceous crocodyliforms from South America by recognizing four basic groups: Notosuchidae, Uruguaysuchidae, Peirosauridae, and Baurusuchidae. These four groups, recognized by Gasparini on the basis of only six different species, represent adaptive morphs that differ from each other in a suite of characters of the rostral region, dentition, and palatal anatomy (Fig. 1).

The diversity of Cretaceous crocodyliforms from South America (and other regions of Gondwana) has remarkably increased since the original studies of Gasparini in the 1970's and 1980's (Carvalho and Bertini, 1999; Ortega et al., 2000; Campos et al., 2001; Carvalho et al., 2004, 2005, 2007, 2011; Pol and Apesteguía, 2005; Nobre and Carvalho, 2006; Andrade and Bertini, 2008; lori and Carvalho, 2009, 2011; Kellner et al., 2009, 2011a,b; Marinho and Carvalho, 2009; Novas et al., 2009; Nascimento and Zaher, 2010; Montefeltro et al., 2011; Martinelli et al., 2012; Marinho et al., 2013). The new discoveries, coupled with the inclusion of both Baurusuchidae and Peirosauridae within Notosuchia in recent phylogenetic studies (e.g., Turner and Sertich, 2010; Pol et al., 2012, 2014), revealed a previously unsuspected diversity of Notosuchian crocodyliforms. There has been an almost 4-fold increase in its known diversity during the last 25 years (Fig. 2). This increase in notosuchian diversity improved our knowledge on the distribution of this clade, both temporally and geographically. The biochron of most notosuchian clades is restricted to the Cretaceous, and ranges from the Aptian (Early Cretaceous) to the Maastrichtian (Late Cretaceous), although a lineage of notosuchians of debated affinities (Sebecidae) is recorded after the K/Pg extinction event, and survived until the Miocene in South America (Gasparini, 1972, 1996; Buffetaut, 1982; Kellner et al., 2014).

From a biogeographic point of view, recent discoveries are highlighting a growing number of Cretaceous notosuchians in other Gondwanan landmasses in addition to South America, such as Africa (Sereno and Larsson, 2009; 
O'Connor et al., 2010; Sertich and O'Connor, 2014) and Madagascar (Buckley and Brochu, 1999; Buckley et al., 2000; Simons and Buckley, 2009). Furthermore, fragmentary (but still informative) remains found in Indo-Pakistan (Wilson et al., 2001; Prasad and de Broin, 2002; Prasad et al., 2013), Central Asia (Chimaerasuchus; Wu and Sues, 1996), and Europe (Company et al., 2005; Dalla Vechia and Cau, 2011; Rabi and Sebök, 2015) suggests that the geographic distribution of Notosuchia was broader than previously thought. The major diversity of Cretaceous notosuchians is, however, still found in South America, where over $70 \%$ of the known species of this group have been recovered (Fig. 2).

These discoveries prompted a growing number of research efforts focused on the anatomy and systematics of notosuchian crocodyliforms. A strong component of recent research on notosuchians has been the use of cladistics analysis for testing the relationships of Notosuchia (Ortega et al., 2000; Pol, 2003; Carvalho et al., 2004; Turner and Sertich, 2010; Andrade et al., 2011; Montefeltro et al., 2011; Pol et al., 2012, 2014). Many of these studies are now corroborating the monophyly of the four Cretaceous clades early recognized by Gasparini for South American forms in pioneer contributions during her early career (i.e., Uruguaysuchidae, Peirosauridae, Baurusuchidae, and a clade allying

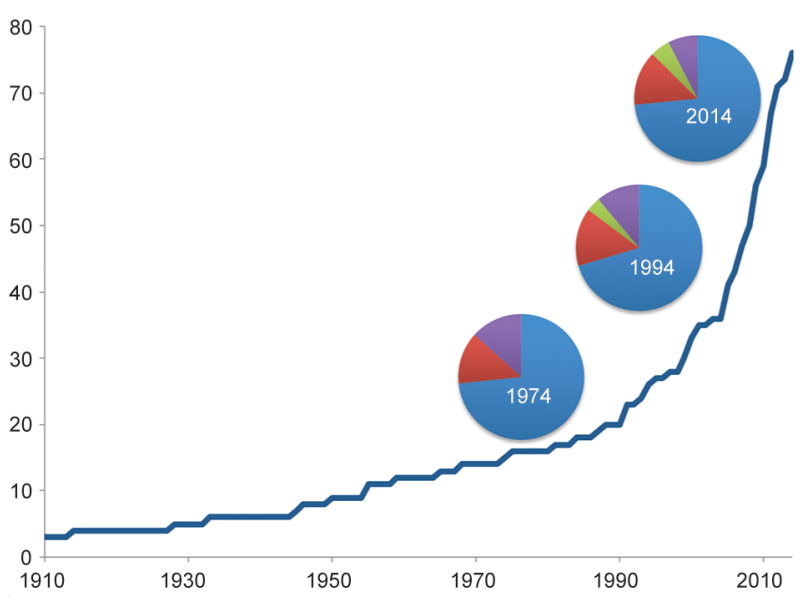

Figure 2. Number of notosuchian species discovered through time (blue curve). The pie charts show the relative geographical distribution of the known diversity in 1974, 1994, and 2014, classified for major landmasses. References: blue: South America; red: Africa; green: Madagascar; purple: other regions (China, Europe, Pakistan).
Notosuchus and closely related forms; Gasparini, 1971, 1972, 1982). In this contribution, we analyze the diversity patterns among notosuchians during the Cretaceous, aiming to evaluate the currently known diversity, the radiation and extinction events of this group of crocodyliforms.

\section{MATERIALS AND METHODS}

\section{Notosuchian diversity}

Notosuchian species. A list of published species of notosuchian crocodyliforms was compiled summarizing the diversity and distribution of the group, including age, geographic and stratigraphic provenance, systematic assignment to five different subgroups of Notosuchia (see below), and year of publication (see Supplementary Information).

Notosuchian phylogeny. The systematic arrangement of notosuchian species was based on recent phylogenetic analyses published by Pol et al. (2014), with subsequent addition of two taxa made by Leardi et al. (2015). These studies were chosen as they are the most comprehensive analyses, in terms of both taxon and character sampling, of notosuchian crocodyliforms performed to date and agree in many aspects with other studies published in recent years (Sereno and Larsson, 2009; Turner and Sertich, 2010; Andrade et al., 2011; Montefeltro et al., 2013; Sertich and O'Connor, 2014). The topologies from these phylogenetic analyses were used for two main purposes. Firstly, the topology served for establishing the clade assignment for each terminal taxon into five major clades recognized within Notosuchia during the Cretaceous (see below). Secondly, the topologies served to perform a phylogenetic correction of diversity based on the inferences of ghost lineages (Norell, 1992) at each period of time (see below). Some notosuchian species were not included in the data matrices published by Pol et al. (2014) and Leardi et al. (2015) and therefore have been excluded from the diversity analyses conducted here, because their absence in the used phylogenetic hypotheses precluded assessing their impact on the phylogenetically corrected diversity measures. These, however, are limited to 18 out of the 77 known species, and may not alter the diversity trends discussed in this paper.

Notosuchian clades. Most recent phylogenetic analyses have recovered a large clade clustering most Cretaceous crocodyliforms from Gondwana (Turner and Sertich, 2010; 
Andrade et al., 2011; Montefeltro et al., 2013; Pol et al., 2012, 2014; Sertich and O'Connor, 2014), creating a relatively recent but broad consensus on the monophyly of Notosuchia and its taxonomic content. The taxonomic content of Notosuchia has been enlarged in comparison with the original proposal by Gasparini (1971; restricted to Notosuchidae+Uruguaysuchidae) and currently includes the Cenozoic Sebecidae and the Cretaceous Peirosauridae (and related forms; Turner and Sertich, 2010; Pol et al., 2012). Although some discrepancies still exist among published phylogenies (e.g., the exclusion of Peirosauridae from Notosuchia), we have based our study on the phylogenetic results of Pol et al. (2014) and for the purpose of assessing diversity patterns we recognize here five major groups of Cretaceous notosuchians (Fig. 3), four of which represent monophyletic clades. These four clades correspond to the four basic taxonomic groups originally identified by Gasparini (although with some differences in their taxonomic content).

The first of them, Uruguaysuchidae (Fig. 3), includes Uruguaysuchus, the now highly diverse Araripesuchus (including six species distributed from the Albian to the Campanian-Maastrichtian; Price, 1959; Buffetaut, 1981; Ortega et al., 2000; Pol and Apesteguía, 2005; Turner, 2006), as well as the bizarrely broad snouted Anatosuchus (Sereno et al., 2003). The second clade, Peirosauridae, includes a variety of Late Cretaceous South American taxa (e.g., Peirosaurus, Lomasuchus, Gasparinisuchus, Uberabasuchus, Montealtosuchus; Price, 1955; Gasparini et al., 1991; Carvalho et al., 2004, 2007; Martinelli et al., 2012) but also closely related African species from the "mid" Cretaceous (e.g., Hamadasuchus, Stolokrosuchus; Larsson and Gado, 2000; Larsson and Sues, 2007). We have included in this group the bizarre but closely related clade Mahajangasuchidae (Fig. 3), recorded in the Cenomanian of Africa and the Campanian-Maastrichtian of Madagascar (Sereno and Larsson, 2009). The third group, here referred as basal ziphosuchians, does not represent a clade but a number of taxa mainly recorded in the "middle" Cretaceous of Africa (Libycosuchus, Malawisuchus, Pakasuchus; Stromer, 1914; Gomani, 1997; O'Connor et al., 2010), South America (Candidodon; Carvalho, 1994), and some relictual forms in the Late Cretaceous (Neuquensuchus, Simosuchus; Buckley et al., 2000; Fiorelli and Calvo, 2007). These forms are clearly closer to advanced notosuchians and sebecosuchians than to uruguaysuchids and peirosaurids but are placed basally within Ziphosuchia. The fourth clade, advanced notosuchians (sensu Pol et al., 2014), is recorded in the Late Cretaceous of South America and includes its basal members (Morrinhosuchus, Notosuchus, Mariliasuchus; Woodward, 1896;

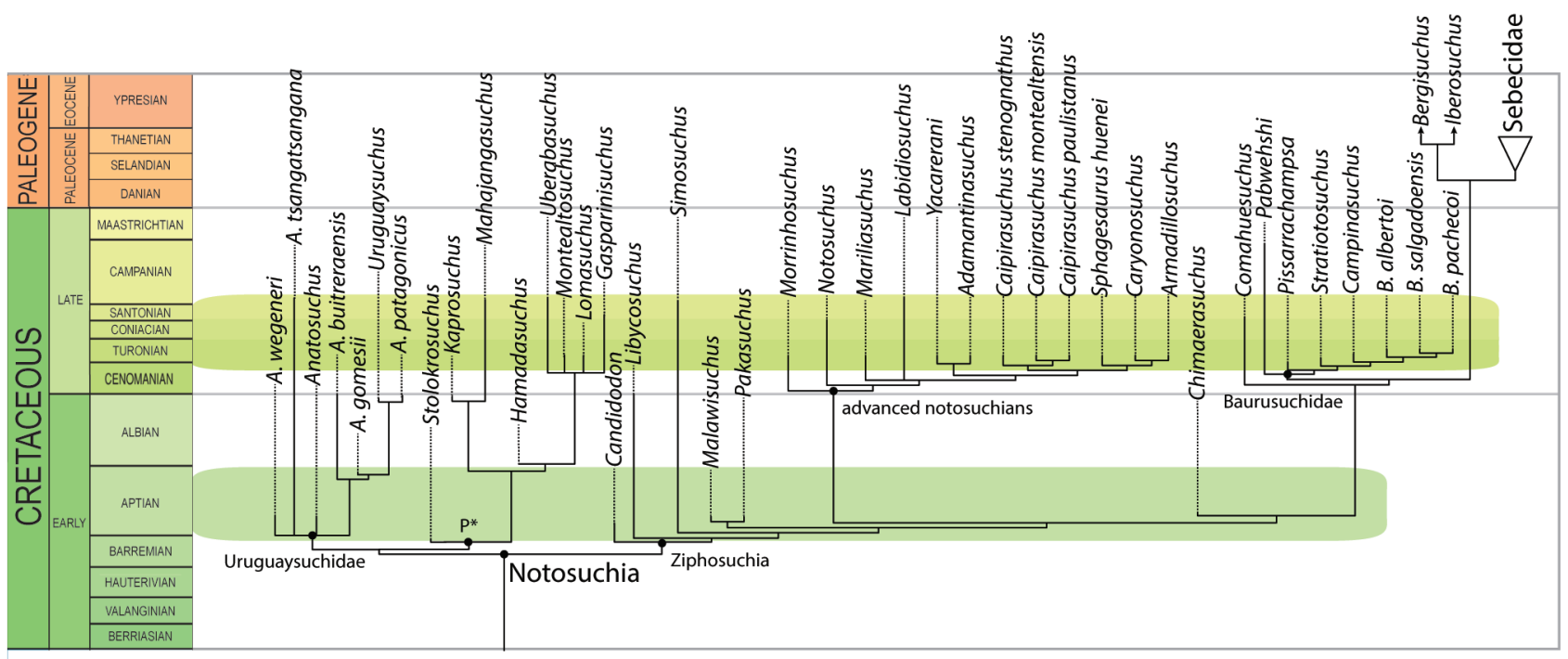

Figure 3. Calibrated phylogeny of Notosuchia based on Pol et al. (2014) and Leardi et al. (2015). P* indicates the clade formed by Peirosauridae and allies (i.e., Mahajangasuchidae). 
Carvalho and Bertini, 1999; lori and Carvalho, 2009) and the diverse Sphagesauridae (Fig. 3). The fifth clade, Baurusuchidae, is mainly recorded in two formations from the middle Late Cretaceous of Argentina (Cynodonthosuchus, Wargosuchus; Woodward, 1896; Martinelli and Pais, 2008) and Brazil (Baurusuchus, Campinasuchus, Pissarrachampsa, Aplestosuchus, Gondwanasuchus; Price, 1945; Carvalho et al., 2011; Montefeltro et al., 2011; Marinho et al., 2013; Godoy et al., 2014; ), with the possible addition of Pabwehshi (Wilson et al., 2001) a fragmentary form found in the Maastrichtian of Pakistan. Finally, although our focus is centered in the Cretaceous, we have grouped the Cenozoic Sebecidae and allies from other regions (e.g., Iberosuchus, Bergisuchus, Doratodon; Kuhn, 1968; Antunes, 1975; Company et al., 2005; Rabi and Sebök, 2015) in a separate group.

\section{Diversity analysis}

The diversity analyses performed here are based on establishing the number of notosuchian lineages present at different periods of time during the Cretaceous. The most basic and raw estimate is the taxic diversity (Levinton, 1988) at a given period of time (i.e., number of species known from that time slice). Different corrections that aim to minimize the bias introduced by the vagaries of the fossil record have been proposed for establishing diversity patterns across time. Here we have explored the use of two commonly used corrections, one that aim to minimize the influence of the uneven distribution of fossiliferous rocks for different periods of time (sampling correction) and other that corrects diversity counts based on lineages inferred from the phylogenetic analysis (phylogenetic correction; Norell and Novacek, 1992a,b).

Time bins. Diversity curves are not only affected by the granularity of the taxonomy (hierarchical taxonomic level) but also by the precision of age assignment for each fossil species. This depends on the nature of the available chronostratigraphic information as well as the questions being tested. Here we have chosen to assign ages based on the geological stages recognized by the International Chronostratigraphic Chart (Cohen et al., 2012). This follows the procedures of recent studies on the diversity dynamics of mesozoic vertebrates (Barrett et al., 2009; Butler et al., 2009; Mannion et al., 2011) and is based on the fact that the age of most Cretaceous continental units from Gondwana is only constrained to one geological stage, at best. Several lithostratigraphic units have uncertain age assignment and are assigned to various contiguous stages (e.g., Aptian-Albian, Turonian-Santonian). The diversity counts of these units have been counted for the stages included in the uncertainty range rather than choosing an arbitrary midpoint age assignment. These may create plateaus in the diversity curves that should be interpreted as chronostratigraphic uncertainty rather than stasis of diversity levels though time.

Sampling correction. The geological record heavily influences our perception of the fossil diversity, in particular limiting the findings of the taxa of interest. It has been demonstrated that the amount of taxa known for a particular time bin is correlated with the number of fossil-bearing formations available (e.g., Behrensmeyer et al., 2000; Miller, 2000; Alroy et al., 2001, 2008). A typical correction used in diversity studies implies the recognition of the fossil-bearing formations for the particular case of study (e.g., Barrett et al., 2009; Butler et al., 2009; Irmis, 2011; Mannion et al., 2011), and afterwards normalizing the diversity curves. In our case, we recognized the notosuchian-bearing formations (NBFs) for each time bin (see Supplementary Information), and the resulting diversity for that period of time was divided by the number NBFs.

Phylogenetic correction. The number of species known for each period of time (taxic diversity) is a minimum estimate on the true diversity due to the incompleteness of the fossil record. Phylogenetic trees provide hypotheses on the existence of lineages prior to their first appearance in the fossil record (ghost lineages sensu Norell, 1992). A ghost lineage extending throughout a period of time implies an undetected lineage that can be added to the known (taxic) diversity, which is the basic rationale of the phylogenetic correction of diversity curves (Norell and Novacek, 1992a,b). Here we have counted an additional lineage to the diversity counts when the phylogenetic topology implied a lineage the spans at least throughout an entire geological stage.

\section{RESULTS}

The diversity of notosuchians varied significantly throughout the Cretaceous. We show first the patterns of overall di- 
versity through time for the clade Notosuchia. Afterwards, we decompose the curves to evaluate the contribution of the different geographic areas and phylogenetic clades to the total diversity of Notosuchia.

\section{Notosuchian diversity curves}

Taxic and phylogenetic diversity. The number of notosuchian species known for each period of time increases in two distinct pulses during the Cretaceous. The first pulse (Fig. 4.1) represents the Aptian radiation of basal notosuchians (see Pol et al., 2014). The notosuchian diversity remains stable during the Aptian-Cenomanian, a stasis that is likely affected by the chronostratigraphic uncertainty of notosuchian bearing formations of the "middle" Cretaceous of South America (e.g., Itapecurú, Guichón) or Africa (Kem Kem, Gadoufaua, Galula). After this stasis, the second pulse of diversification (Fig. 4.1) occurs later during the Late Cretaceous, presumably between the Turonian and Santonian, where the highest peak of notosuchian diversity is achieved (Turonian-Santonian radiation sensu Pol et al., 2014). The precise timing of this radiation depends on the age of certain formations from South America (e.g., Adamantina, Bajo de la Carpa; see Pol et al., 2014 and Discussion below). Drastic drops in diversity are recorded at the end Cretaceous (most likely Campanian-Maastrichtian) that reduced the diversity of Cretaceous notosuchians, of which only one lineage (sebecids) survives the K/Pg extinction event.

The phylogenetic correction shows that the periods of time in which there are more unsampled lineages are precisely the timespan during which most notosuchians are known (Aptian-Santonian; light grey curve in Fig. 4.1). This indicates that both the Aptian and the Turonian-Santonian radiation events were larger than what the direct reading of the fossil record (i.e., taxic diversity) implies. In our analysis, the phylogenetic correction almost does not make any difference before the Aptian or after the Santonian, implying that our phylogenetic tree does not indicate that unsampled lineages are biasing the estimates of low notosuchian diversity outside the Aptian-Santonian timespan.

Sampling correction. The sampling correction provides an overall similar pattern of diversity, with two pulses of diversification (Aptian and Turonian-Santonian) and a drastic drop in diversity at the latest Cretaceous (Fig. 4.2). However, there are two most notable differences with respect to the diversity curves uncorrected for uneven sampling. The first of them is that the first diversification pulse reaches a peak by the Aptian but then is followed by a decrease in diversity (corrected by sampling) during the Albian and Cenomanian (Fig. 4.2) rather than a diversity stasis. This drop is caused by the fact that there are a similar number of notosuchian

\section{(1)}

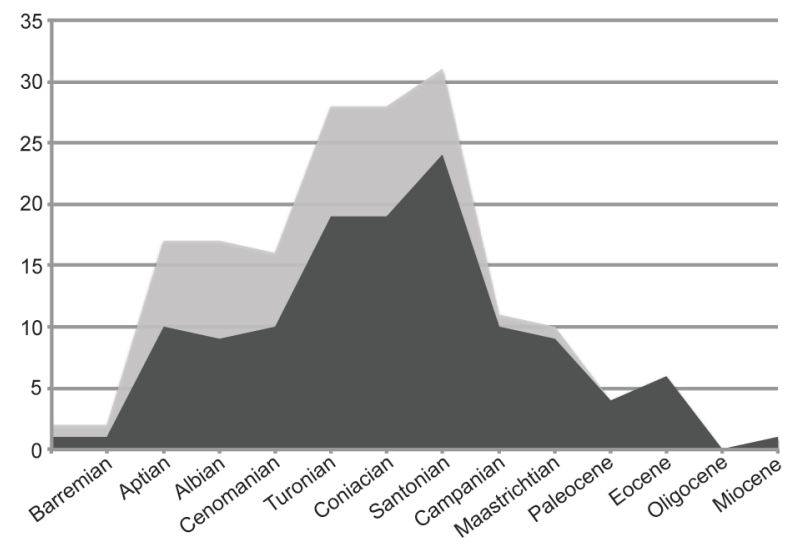

(2)

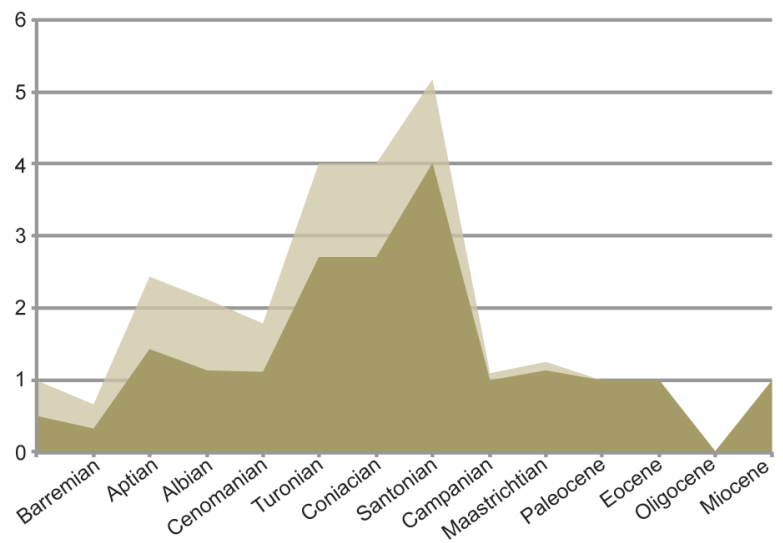

Figure 4. Diversity curves of Notosuchia through time. 1, Taxic diversity (dark grey) and phylogenetically corrected diversity counting ghost lineages (light grey), with vertical axis representing total number of species (taxic) or species plus ghost lineages (phylogenetic correction) per period of time. 2, Taxic (dark brown) and phylogenetically corrected (light brown) diversity corrected by sampling of fossiliferous units, with vertical axis representing the taxic or phylogenetic diversity divided by the number of notosuchian bearing formations per unit of time. 
taxa (or lineages) known for these three stages, but there are more notosuchian bearing formations for the Cenomanian (nine) than for the Aptian (seven) so that the diversity relative to the number of sampling units is lower. The second difference is found in the diversity dynamics across the $\mathrm{K} / \mathrm{Pg}$ mass extinction event. When the diversity is uncorrected by sampling there is a drastic drop in diversity between the Maastrichtian and the Paleocene (Fig. 4.1) whereas there is only a minor decrease in diversity across the K/Pg boundary when the diversity is corrected by uneven sampling (Fig. 4.2). The end Cretaceous known diversity is indeed higher than in the Paleocene (11 species versus 4 species) but the number of units for these two periods of time is also markedly different. The apparent insensitivity of notosuchians to the mass extinction event inferred from the diversity curve corrected by sampling is nonetheless a product of lumping all notosuchians within a single taxonomical category (see below).

\section{Diversity patterns of Notosuchia across Gondwana}

As noted above, although close to $75 \%$ of the known notosuchian diversity is found in South America (Fig. 2), there is a large number of notosuchian species known from Africa, Madagascar, and other regions of the world. The diversity of Notosuchia varies not only over time but also through space. The geographically split diversity curves aim to show the different contributions of Gondwanan landmasses during the Cretaceous (Fig. 5.1).

The first diversification event (Aptian radiation) is largely formed by the African fossil record (Fig. 5.1), which accounts for more than half the known notosuchian diversity in the Early Cretaceous. The large African contribution to this radiation is surely influenced by the numerous notosuchians discovered in highly fossiliferous deposits of Niger (Sereno and Larsson, 2009) but also in other regions of Africa (e.g., Tanzania, Malawi, Egypt, Morocco; Stromer, 1914; Gomani, 1997; Sereno and Larsson, 2009; O'Connor et al., 2010; Sertich and O'Connor, 2014). The contribution of the South American fossil record to the first diversification pulse is second to the African contribution and increases towards the Cenomanian. The record in other landmasses is limited to the Aptian-Albian Chimaerasuchus paradoxus from China (Wu et al., 1995).

The second diversification pulse (referred as the Turonian-Santonian radiation) is exclusively formed by the South American fossil record (Fig. 5.1), which accounts for the major diversity peak in the history of Notosuchia. This is undoubtedly influenced by the remarkable diversity of no-

\section{(1)}

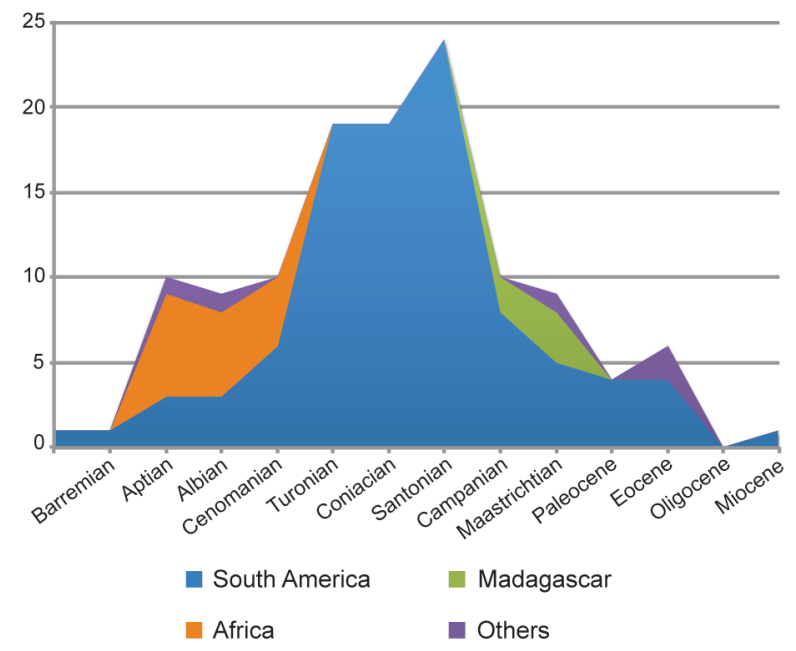

(2)

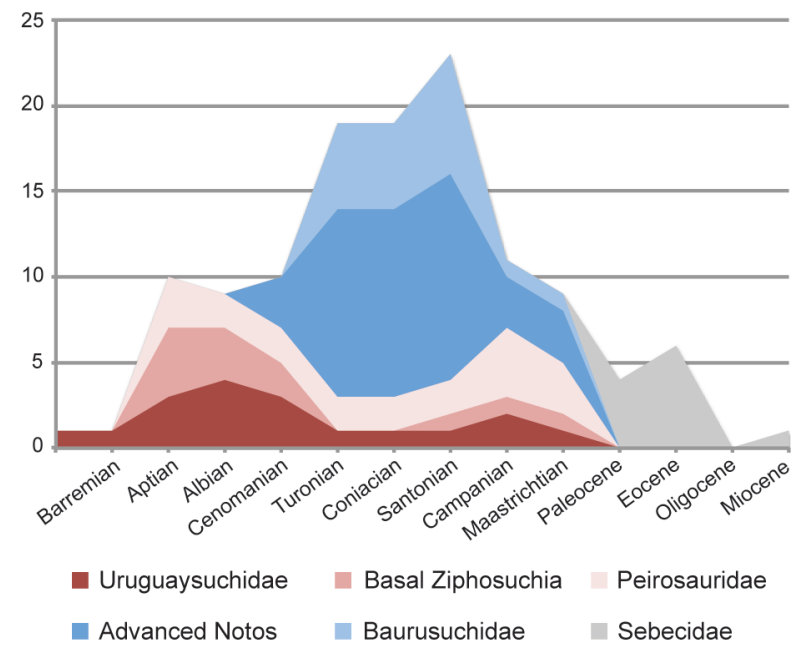

Figure 5. Taxic diversity of Notosuchia split by 1, geographical regions and 2, different notosuchian groups across time. For each period of time the different contributions of each region or clade are on top of each other so that the sum equals the taxic diversity shown in Figure 4.1. 
tosuchians in the Adamantina Formation in Brazil and the Neuquén Group in northwestern Patagonia (see Pol et al., 2014), which represents a major radiation not only in terms of the number of taxa but also in the ecological diversity of the group known from these units (Godoy et al., 2014). As noted above, some authors regard the age of this unit as younger than Turonian-Santonian (e.g., Gobbo-Rodrigues et al., 1999; Fernandes and Coimbra, 2000) and therefore this diversity peak may be displaced slightly later, towards the Campanian (see below).

By the latest Cretaceous (Campanian-Maastrichtian), notosuchian diversity falls to half the number of species known from the preceding diversity peak. Although the decrease in South American diversity is steep, this landmass still contributes to more than half of the known diversity in the latest Cretaceous (Fig. 5.1). An important contribution to the Campanian-Maastrichtian diversity is found in Madagascar (Maevarano Formation; Buckley and Brochu, 1999; Buckley et al., 2000; Turner, 2006; Rasmusson Simons and Buckley, 2009). Other regions have provided records of ziphodont crocodyliforms by the end Cretaceous linked to different groups of notosuchians, such as Europe (Company et al., 2005) or Pakistan (Wilson et al., 2001). After the K/Pg extinction event the diversity of notosuchians is mainly restricted to South America, with minor contributions from other regions (Fig. 5.1), such as Europe (e.g., Iberosuchus, Bergisuchus; Antunes, 1975; Ortega et al., 1996; Ortega, 2004) although possible notosuchian remains have also been reported from the Paleogene of Africa (Eremosuchus; Buffetaut, 1989).

\section{Diversity patterns of notosuchian subclades}

The diversity of Notosuchia as a whole varies markedly during the Cretaceous, and this variation responds to the sum of evolutionary dynamics of the different notosuchian subclades. The taxic diversity curves of the five major groups of Cretaceous notosuchians reveal that different clades diversify and become extinct at different times (Fig. 5.2). Three of the five groups (basal members of Ziphosuchia, uruguaysuchids, and peirosaurids) show a similar pattern of taxic diversity: they early diversify and form the first pulse of diversification during the "middle" Cretaceous (AptianCenomanian), followed by a period of low diversity in the
Turonian-Santonian, a minor diversity peak during the latest Cretaceous (Campanian-Maastrichtian), and a complete extinction by the end of the Mesozoic (Fig. 5.2). The two other groups (advanced notosuchians and baurusuchids) differ markedly from this pattern of diversification, but their diversity curves closely resemble to each other. These two groups form the major diversification peak of Notosuchia (Turonian-Santonian) but have extremely low taxic diversity before and after this period.

Uruguaysuchids have an initial diversity represented by the Araripesuchus species from South America and Africa and the African Anatosuchus. This group apparently becomes extinct throughout Gondwana, except for Madagascar, where a lineage of Araripesuchus survived until the latest Cretaceous ( $A$. tsangatsangana; Turner, 2006). The age of Uruguaysuchus from South America, however, is uncertain (Soto et al., 2011) and precludes defining the mid-Cretaceous extinction of uruguaysuchids in South America more confidently.

The basal ziphosuchians follow a similar pattern of diversity as uruguaysuchids (Fig. 5.2), having a high initial diversification that is broadly distributed, but dominated by the "middle" Cretaceous African record (Libycosuchus, Pakasuchus, Malawisuchus). Subsequently basal ziphosuchians become extinct, except in Madagascar where a surviving lineage is represented by the aberrant Simosuchus in the latest Cretaceous (Buckley et al., 2000; Turner and Sertich, 2010).

Peirosaurids (and closely related forms) also have their initial diversity in the Aptian and through the "middle" Cretaceous, being recorded in South America (Barcinosuchus; Leardi and Pol, 2009) and Africa (Hamadasuchus, Stolokrosuchus, Kaprosuchus; Larsson and Gado, 2000; Larsson and Sues, 2007; Sereno and Larsson, 2009). However, they differ slightly from the two previous groups in that they are recorded in South America throughout the rest of the Cretaceous, during the Turonian-Santonian (Lomasuchus, Gasparinisuchus, Montealtosuchus; Gasparini et al., 1991; Carvalho et al., 2007; Martinelli et al., 2012) and the latest Cretaceous (Peirosaurus, Uberabasuchus; Price 1955; Carvalho et al., 2004). The latest Cretaceous diversity of the group is also present in Madagascar, contributing to their higher diversity at the end-Cretaceous in comparison with 
their initial peak of diversity in the Early Cretaceous (Fig. 5.2).

Advanced notosuchians (the group to which Notosuchus belongs) are exclusively known from South America and are virtually unknown prior to the Turonian-Santonian. The only pre-Turonian record is Coringasuchus anisodontis from the Cenomanian of Brazil (Kellner et al., 2009), a taxon known from fragmentary remains and of uncertain affinities within the clade of advanced notosuchians (Pol et al., 2014). This group has a remarkable diversity during the Turonian-Santonian in South America (over half of the notosuchian taxic diversity known from this period of time; Fig. 5.2). This diversity is dominated by the numerous species of sphagesaurids known from the Adamantina Formation of Brazil (Pol et al., 2014). After their diversity acme, advanced notosuchians are rare and the only known advanced notosuchian from the latest Cretaceous is Labidiosuchus amicum (Kellner et al., 2011b), a taxon known from partial dentary remains from the Marilia Formation (Campanian-Maastrichtian) of Brazil. The precise age of this diversity peak is slightly uncertain as there are authors that propose the Adamantina Formation is younger in age than Turonian-Santonian (see below) and because two other advanced notosuchians have been found in units with poorly constrained ages (e.g., Late Cretaceous) of Bolivia (Yacarerani; Novas et al., 2009) and Argentina (Fiorelli et al., 2014). Therefore the diversity peak of this group interpreted here as the Turonian-Santonian acme could be slightly younger (toward the Campanian). As all other groups, advanced notosuchians become completely extinct by the end of the Cretaceous.

Baurusuchids are also known exclusively from South America and they are completely absent from the fossil record prior to the Turonian-Santonian (Fig. 5.2). Their sudden appearance occurs with high diversity levels, accounting for approximately $30 \%$ of the taxic diversity known from this period of time. As in the case of advanced notosuchians, this diversity is also dominated by the records from the Adamantina of Brazil (Baurusuchus spp., Campinasuchus, Pissarachampsa, Gondwanasuchus), with the addition some records from the Santonian (sensu Garrido, 2010) Bajo de la Carpa Formation of Patagonia (Fig. 5.2). After their diversity peak, there are no definitive baurusuchids known in the fossil record. The two possible exceptions are
Pehuenchesuchus enderi from Patagonia (Campanian sensu Garrido, 2010) and Pabwehshi pakistanensis from Pakistan (Maastrichtian; Wilson et al., 2001), but the former has uncertain affinities within Sebecosuchia (Pol et al., 2014) and the latter has been retrieved as a peirosaurid by some phylogenetic analyses (e.g., Larsson and Sues, 2007). Despite their possible survival until the end Cretaceous there are no remains of this clade after the K/Pg boundary.

\section{DISCUSSION}

The diversity patterns shown above reveal the complex dynamics of notosuchian evolution during the Cretaceous, which high lights the components across space of two successive diversification pulses followed by two distinct extinction events that shaped the diversity curves of this clade. Despite the implemented phylogenetic and sampling corrections, these increases and drops in diversity are undoubtedly affected by the vagaries of the fossil record. Here we discuss these four events considering first the radiations and then the extinction events.

\section{Aptian radiation}

As shown above the first pulse of diversification in Notosuchia involves the sudden appearance in the Aptian in the fossil record of three major clades, Uruguaysuchidae, Peirosauridae (and allies), and basal lineages of Ziphosuchia (Fig. 5.2). These clades are the three most basal lineages of Notosuchia and their initial diversification implies the existence of multiple ghost lineages during the Early Cretaceous (Fig. 2), which led the proposal of this event as the Aptian radiation by Pol et al. (2014). A problematic point related to this diversification event is the almost exclusive absence of notosuchians during the earliest Cretaceous (BerriasianBarremian), which hampers our understanding of the evolutionary dynamics of this event (Pol et al., 2014). The absence of pre-Aptian notosuchians is most likely influenced by the overall scarce fossil record of continental crocodyliforms during the earliest Cretaceous, which contrasts with the denser sampling available for the Aptian-Albian (e.g., eight notosuchian bearing formations). Such situations may create an artificial pattern of sudden radiation even when the diversification of these groups was much more gradual and scattered through time. The only evidence suggesting this 
indeed may be the case is Amargasuchus minor (Chiappe, 1988), known from a fragmentary maxillary found at the Puesto Antigual Member of the La Amarga Formation (Barremian). Amargasuchus was originally described as a member of Trematochampsidae, a group of questioned validity but usually regarded as closely related to or nested within Peirosauridae (Gasparini et al., 1991; Sertich and O'Connor, 2014). Furthremore, Gasparini et al. (1991) noted similarities between this fragmentary form and the peirosaurid Lomasuchus. The putative existence of a peirosaurid, or even a taxon closely related to this clade, in the Barremian would push the initial split of the basal notosuchian lineages back to this stage. Furthermore, this would decouple the diversification of peirosaurids from that of uruguaysuchids and basal ziphosuchians, therefore questioning the existence of an Aptian radiation event. New information of the earliest Cretaceous can easily influence current hypotheses on the initial diversification of Notosuchia, even if they are based on fragmentary material such as the case of the possible notosuchian Amargasuchus.

\section{Turonian-Santonian radiation}

The major peak of notosuchian diversity is interpreted here as representing the Turonian-Santonian radiation (Fig. 4), and the diversity curves split by geography and subclades show this is largely formed by two South American groups: advanced notosuchians and baurusuchids (Fig. 5). The well-sampled pre-Turonian units of different regions of Gondwana, in which these two groups are absent, provide support for interpreting this peak of diversity as a true radiation event during the Late Cretaceous (Turner and Sertich, 2010; Pol et al., 2014). As noted by several authors (e.g., Montefeltro et al., 2011; Pol et al., 2014; Martinelli and Teixeira, 2015), there is some uncertainty related to the age of the Adamantina Formation, which provides over $80 \%$ of the known taxic diversity of advanced notosuchians and baurusuchids. Such uncertainty may imply this radiation event occurred in South America during the SantonianCampanian rather than during the Turonian-Santonian. Despite these uncertainties, it seems clear the existence of a remarkable radiation of baurusuchids and advanced notosuchians (especially sphagesaurids) that shaped dynamics of the terrestrial ecosystems in the middle Late
Cretaceous in South America (e.g., Godoy et al., 2014), especially in warm and dry (or seasonal) environments (Carvalho et al., 2010).

Whereas the existence of this radiation in South America is robustly supported, its endemic nature to South America cannot be adequately tested by the currently available fossil record. Notosuchian remains from other regions during the Turonian-Santonian are extremely scarce, partly because there are no fossiliferous units of this age in Africa, Madagascar, or other regions of Gondwana. Although not included in our analysis, there are fragmentary remains of alleged notosuchian affinities from Europe (Dalla Vechia and Cau, 2011; Rabi and Sebök, 2015) but these most likely do not belong to the groups that radiated in South American during this time (i.e., advanced notosuchians and baurusuchids). The absence of relevant fossil and rock record therefore precludes determining with certainty if advanced notosuchians or baurusuchids were present in other regions of Gondwana during the middle Late Cretaceous. Data from the latest Cretaceous (Campanian-Maastrichtian) of other regions of Gondwana could provide hints regarding this point, but the available information is inconclusive. On the one hand, the absence of advanced notosuchians or baurusuchids in the diverse crocodyliform fauna of the latest Cretaceous Maevarano Formation of Madagascar (Krause et al., 2006) suggests the South American endemism of these two groups may be real, given that this unit records survival lineages of all other notosuchian clades (e.g., uruguaysuchids, peirosaurids, basal ziphosuchians). On the other hand, if the possible baurusuchid affinities of Pabwehshi from the Maastrichtian of Pakistan are corroborated by more complete remains (e.g., preserving the choanal region), it would significantly expand the geographic scope of this clade across Gondwana. New data and crocodyliform remains from the middle Late Cretaceous of Africa, Madagascar, and other regions of Gondwana will be critical for adequately testing the South American endemism of the major radiation in the history of Notosuchia.

\section{Extinction patterns in Notosuchia}

Campanian event. The first marked drop in diversity in the history of Notosuchia is recorded at the beginning of the Campanian (Figs. 4-5) and is caused by the complete ex- 
tinction of baurusuchids and the drastic decrease in diversity of advanced notosuchians in South America (Fig. 5). This decrease, at least in South America, seems to be a real extinction event given that other groups of crocodyliforms are recorded in the same geographic regions (e.g., southern Brazil, northwestern Patagonia). The above-mentioned uncertainty regarding the age of the Adamantina Formation and its impact on the timing of the middle Late Cretaceous diversity peak also affects the timing of this extinction event. If this formation is indeed younger than TuronianSantonian as proposed by some researchers (Gobbo-Rodrigues et al., 1999; Fernandes and Coimbra, 2000), this extinction event would have occurred later than the Campanian but before the end of the Cretaceous Period. From a stratigraphic perspective, and given the dominance of the Bauru Group in the notosuchian diversity curves, the extinction event is nonetheless placed at the transition between the Adamantina and the Marilia formations. The extent of this extinction event in other regions of Gondwana is largely unknown due to the above-mentioned lack of Turonian-Santonian crocodyliform record.

K/Pg event. Although the major decrease of notosuchian diversity occurred well before the end of the Cretaceous Period, the K/Pg mass extinction event certainly affected notosuchians. The five groups of Cretaceous notosuchians analyzed here (with the possible exception of Baurusuchidae) were still present during the latest Cretaceous (Fig. 5.2) but became completely extinct by the end of the Mesozoic. The only notosuchians that survive this mass extinction event are sebecids (and related forms recorded in the Paleogene of Europe and Africa; Buffetaut, 1989; Ortega et al., 1996; Ortega, 2004). This group has been phylogenetically allied either to baurusuchids (forming the clade Sebecosuchia; see Pol and Powell, 2011) or to peirosaurids (forming the clade Sebecia; see Larsson and Sues, 2007). Irrespective of their debated affinities, this distinct clade of notosuchians has its closest relatives in the Cretaceous and therefore must have been originated prior to the K/Pg boundary. This is the only notosuchian lineage that survived the mass extinction event (Gasparini, 1972, 1996; Buffetaut, 1982; Kellner et al., 2014) and subsequently became abundant during the Paleogene, especially in South America (Fig. 5.1-2).

\section{CONCLUSIONS}

The analysis of notosuchian diversity patterns reveals four basic episodes that shaped the evolutionary dynamics of this group, involving two successive diversification events and two consecutive extinction events that wiped out the outstanding diversity of the group by the latest Cretaceous. The currently available fossil record indicates the first diversification pulse (Aptian radiation) was geographically widespread across Gondwana (and possibly other regions of the globe) and involved the basal lineages of Notosuchia (Uruguaysuchidae, Peirosauridae and allies, and basal forms of Ziphosuchia). However, the remarkably scarce record of pre-Aptian crocodyliforms suggests this may have not been a simultaneous event. In contrast, the second pulse of diversification during the middle Late Cretaceous (possibly Turonian-Santonian) is likely a true and outstanding radiation event (at least in South America) of the highly diverse advanced notosuchians and baurusuchids.

Two consecutive but distinct extinction events are inferred to occur during the latest Cretaceous (CampanianMaastrichtian). The former of which records the almost complete disappearance of advanced notosuchians and baurusuchids, leaving a depauperated taxic diversity of notosuchians during the latest Cretaceous that were subsequently affected by the end-Cretaceous mass extinction.

Different regions of Gondwana have provided critical evidence for understanding the evolutionary pattern of Notosuchia at different periods of time during the Cretaceous. South America dominates the notosuchian fossil record and basically shapes the diversity curve during the entire Late Cretaceous. Most of what we currently know about notosuchian evolution and diversity would be just impossible to infer without the contribution of the South American fossil record. The African fossil record has been pivotal for understanding the initial diversification of the basal lineages of Notosuchia and shapes the diversity curves during the "middle" Cretaceous (Aptian-Cenomanian). Finally, the latest Cretaceous record of Madagascar is relevant as it shows the survival of lineages (i.e., uruguaysuchids and basal ziphosuchians) that became extinct in other regions of Gondwana earlier during the Cretaceous. 


\section{ACKNOWLEDGMENTS}

This contribution aims to provide a synthesis of current knowledge of a group whose modern understanding was founded by Zulma Gasparini over 40 years ago, when she was a young researcher working in her doctoral dissertation. Her influence in our field is undeniable, but Zulma has been even more important in terms of supporting, helping and fostering the early careers of numerous researchers in Argentina. We therefore would like to thank Zulma for her influence and help to us (and a large number of other people) during the last years. We also would like to thank M.S. Fernández and Y. Herrera for inviting us to contribute a chapter of this special issue, and for assembling this issue dedicated to Zulma. Funds for this project were provided by the Agencia Nacional de Promoción Científica y Técnica (PICT 2010-0756, 2013-0132, 2013-2725). This is JML's R-166 contribution to the Instituto de Estudios Andinos Don Pablo Groeber.

\section{REFERENCES}

Alroy, J., Aberhan, M., Bottjer, D.J., Foote, M., Fürsich, F.T., Harries, P.J., Hendy, A.J.W., Holland, S.M., Ivany, L.C., Kiessling, W., Kosnik, M.A., Marshall, C.R., McGowan, A.J., Miller, A.I., Olszewski, T.D., Patzkowsky, M.E., Peters, S.E., Villier, L., Wagner, P.J., Bonuso, N., Borkow, P.S., Brenneis, B., Clapham, M.E., Fall, L.M., Ferguson, C.A., Hanson, V.L., Krug, A.Z., Layou, K.M., Leckey, E.H., Nürnberg, S., Powers, C.M., Sessa, J.A., Simpson, C., Tomasovych, A., and Visaggi, C.C. 2008. Phanerozoic trends in the global diversity of marine invertebrates. Science 321 : 97-100.

Alroy, J., Marshall, C.R., Bambach, R.K., Bezusko, K., Foote, M., Fürsich, F.T., Hansen, T.A., Holland, S.M., Ivany, L.C., Jablonski, D., Jacobs, D.K., Jones, D.C., Kosnik, M.A., Lidgard, S., Low, S.A., Miller, I., Novack- Gottshall, P.M., Olszewski, T.D., Patzkowsky, M.E., Raup, D.M., Roy, K., Sepkoski, JR., J.J., Sommers, M.G., Wagner, P.J., and Webber, A. 2001. Effects of sampling standardization on estimates of Phanerozoic marine diversification. Proceedings of the National Academy of Sciences USA 98: 62616266.

Andrade, M.B., and Bertini, R.J. 2008. A new Sphagesaurus (Mesoeucrocodylia: Notosuchia) from the Upper Cretaceous of Monte Alto City (Bauru Group, Brazil) and a revision of Sphagesauridae. Historical Biology 20: 101-136.

Andrade, M.B., Edmonds, R., Benton, M.J., and Schouten, R. 2011. A new Berriasian species of Goniopholis (Mesoeucrocodylia, Neosuchia) from England, and a review of the genus. Zoological Journal of the Linnean Society 163: S66-S108.

Antunes, M.T. 1975. Iberosuchus, crocodile Sebecosuchien nouveau, I'Eocene iberique au Nord de la Chaine Centrale, et I'origine du canyon de Nazare. Comunicações dos Serviços Geológicos de Portugal 59: 285-330.

Barrett, P.M., McGowan, A.J., and Page, V. 2009. Dinosaur diversity and the rock record. Proceeding of the Royal Society B 276: 2667-2674.

Behrensmeyer, A.K., Kidwell, S.M., and Gastaldo, R.A. 2000. Taphonomy and paleobiology. In: D.H. Erwin, and S.L. Wing (Eds.), Deep Time: Paleobiology's Perspective. Supplement to Paleobiology 26(4): 101-147.

Buckley, G.A., and C.A. Brochu. 1999. An enigmatic new crocodile from the Upper Cretaceous of Madagascar. In: D.M. Unwin (Ed.), Cretaceous Fossil Vertebrates. Special Papers in Palaeontology 60. The Palaeontological Association, London, p. 149-175.

Buckley, G.A., Brochu, C.A., Krause, D.W., and Pol, D. 2000. A pugnosed crocodyliform from the Late Cretaceous of Madagascar.
Nature 405: 941-944.

Buffetaut, E. 1981. Die biogeographische Geschichte der Krokodilier, mit Beschreibung einer neuen Art, Araripesuchus wegneri. Geologischen Rundschau 70: 611-624.

Buffetaut, E. 1982. Radiation evolutive, paleoécologie et biogéographie des crocodiliens mesosuchiens. Memoires de la Société Géologique de France 60: 1-88.

Buffetaut, E. 1989. A new ziphodont mesosuchian crocodile from the Eocene of Algeria. Palaeontographica 208: 1-10.

Butler, R.J., Barrett, P.M., Nowbath, S., and Upchurch, P. 2009. Estimating the effects of sampling biases on pterosaur diversity patterns: implications for hypotheses of bird/pterosaur competitive replacement. Paleobiology 35: 432-446.

Campos, D.A., Suárez, J.M., Riff, D., and Kellner, A.W.A. 2001. Short Note on a new Baurusuchidae (Crocodyliformes, Metasuchia) from the Upper Cretaceous of Brazil. Boletim do Museu Nacional, Nova Série, Geologia 57: 1-7.

Carvalho, I.S. 1994. Candidodon: um crocodilo com heterodontia (Notosuchia, Cretáceo Inferior-Brasil). Anais da Academia Brasileira de Ciências 66: 331-345.

Carvalho, I.S., and Bertini, R.J. 1999. Mariliasuchus, um novo Crocodylomorpha (Notosuchia) do Cretáceo da Bacia Bauru, Brasil. Revista Geología Colombiana 24: 83-105.

Carvalho, I.S, Campos, A.C., and Nobre, P.H. 2005. Baurusuchus salgadoensis, a new Crocodylomorpha from the Bauru Basin (Cretaceous), Brazil. Gondwana Research 8: 11-30.

Carvalho, I.S., Gasparini, Z., Salgado, L., Vasconcellos, F.M., and Marinho, T.S. 2010. Climate's role in the distribution of the Cretaceous terrestrial Crocodyliformes throughout Gondwana. Palaeogeography, Palaeoclimatology, Palaeoecology 297: 252-262.

Carvalho, I.S., Ribeiro, L.C.B., and Ávila, L.S. 2004. Uberabasuchus terrificus sp. nov., a New Crocodylomorpha from the Bauru Basin (Upper Cretaceous), Brazil. Gondwana Research 7: 975-1002.

Carvalho, I.S., Teixeira, V.P., Ferrazm, N.L., Ribeiro, L.C., Martinelli, A.G., Neto, F.M., Sertich, J.J., Cunha, G.C., Cunha, I.C., and Ferraz, P.F. 2011. Campinasuchus dinzi gen. et sp. nov., a new Late Cretaceous baurusuchid (Crocodyliformes) from the Bauru Basin, Brazil. Zootaxa 2871: 19-42.

Carvalho, I.S., Vasconcellos, F.M., and Tavares, S.A.S. 2007. Montealtosuchus arrudacamposi, a new peirosaurid crocodile (Mesoeucrocodylia) from the Late Cretaceous Adamantina Formation of Brazil. Zootaxa 1607: 35-46.

Chiappe, L.M. 1988. A new trematochampsid crocodile from the Early Cretaceous of north-western Patagonia, Argentina and its palaeobiogeographical and phylogenetic implications. Cretaceous Research 9: 379-389.

Cohen, K.M., Finney, S.C., Gibbard, P.L., and Fan, J.-X. 2012. The ICS International Chronostratigraphic Chart. Episodes 36: 199-204.

Company, J., Suberiola, X.P., Ruiz Omeñaca, J.I., and Buscalioni, A.D. 2005. A new species of Doratodon (Crocodyliformes: Ziphosuchia) from the Late Cretaceous of Spain. Journal of Vertebrate Paleontology 25: 343-353.

Dalla Vechia, F.M., and Cau, A. 2011. The first record of a notosuchian crocodyliform form Italy. Rivista Italiana di Paleontologia e Stratigrafia 117: 309-321.

Fernandes, L.A., and Coimbra, A.M. 2000. Revisaõ estratigráfica da parte oriental da Bacia Bauru (Neocretáceo). Revista Brasileira de Geociências 30: 717-728.

Fiorelli, L.E., and Calvo, J.O. 2007. The first "protosuchian" (Archosauria: Crocodyliformes) from the Cretaceous (Santonian) of Gondwana. Arquivos do Museu Nacional, Rio de Janeiro 65: 417-459. 
Fiorelli, L.E., Hechenleitner, E.M., Pol, D., Leardi, J.M., and GrelletTinner, G. 2014. The first notosuchian crocodyliform from the Cretaceous of La Rioja, Argentina. Ameghiniana, Suplemento Resúmenes 51: 10

Garrido, A.C. 2010. Estratigrafía del Grupo Neuquén, Cretácico Superior de la Cuenca Neuquina (Argentina): nueva propuesta de ordenamiento litoestratigráfico. Revista del Museo Argentino de Ciencias Naturales, nueva serie 12: 121-177.

Gasparini, Z. 1971. Los Notosuchia del Cretácico de América del Sur como un nuevo infraorden de los Mesosuchia (Crocodilia). Ameghiniana 8: 83-103.

Gasparini, Z. 1972. Los Sebecosuchia (Crocodilia) del territorio argentino. Consideraciones sobre su "status" taxonómico. Ameghiniana 9: 23-34.

Gasparini, Z. 1981. Los Crocodylia fósiles de la Argentina. Ameghiniana 18: 177-205.

Gasparini, Z. 1982. Una nueva familia de cocodrilos zifodontes cretácicos de América del Sur. $5^{\text {to }}$ Congreso Latinoamericano de Geología (Buenos Aires), Actas 4: 317-329.

Gasparini, Z. 1996. Biogeographic evolution of the South American crocodilians. In G. Arratia (Ed.), Contributions of Southern South America to Vertebrate Paleontology. Münchner Geowissenschtaftliche Abhandlungen A 30: 159-184.

Gasparini, Z., Chiappe, L., and Fernández, M. 1991. A new Senonian peirosaurid (Crocodylomorpha) from Argentina and a synopsis of the South American Cretaceous crocodilians. Journal of Vertebrate Paleontology 11: 316-333.

Gobbo-Rodrigues, S.R., Petri, S., and Bertini, R.J. 1999. Ocorrências de ostracodes na Formação Araçatuba do Grupo Bauru, Cretáceo Superior da Bacia do Paraná, e possibilidades de correlação com depósitos isocronos argentinos - Parte 1: Família Ilyocyprididae. Acta Geologica Leopoldinense 23: 3-13.

Godoy, P.L., Montefeltro, F.C., Norell, M.A., and Langer, M.C. 2014. An Additional Baurusuchid from the Cretaceous of Brazil with Evidence of Interspecific Predation among Crocodyliformes. PLOS ONE 9: e97138. Doi:10.1371/journal.pone.0097138.

Gomani, E.M. 1997. A crocodyliform from the Early Cretaceous Dinosaur Beds, Northern Malawi. Journal of Vertebrate Paleontology 17: 280-294.

Iori, F.V., and Carvalho, I.S. 2009. Morrinhosuchus luziae, um novo Crocodylomorpha Notosuchia da Bacia Bauru, Brasil. Revista Brasileira de Geociências 39: 717-725.

Iori, F.V., and Carvalho, I.S. 2011. Caipirasuchus paulistanus, a new sphagesaurid (Crocodylomorpha, Mesoeucrocodylia) from the Adamantina Formation (Upper Cretaceous, Turonian-Santonian), Bauru Basin, Brazil. Journal of Vertebrate Paleontology 31: 12551264.

Irmis, R.B.I. 2011. Evaluating hypotheses for the early diversification of dinosaurs. Earth and Environmental Science Transactions of the Royal Society of Edinburgh 101: 397-426.

Kellner, A.W.A., Campos, D.A., Riff, D., and Andrade, M.B. 2011a. A new crocodylomorph (Sphagesauridae, Notosuchia) with hornlike tubercles from Brazil. Zoological Journal of the Linnean Society 163: S57-S65.

Kellner, A.W.A., Figueiredo, R.G., Azevedo, S.A.K., and Campos, D.A. 2011b. A new cretaceous notosuchian (Mesoeucrocodylia) with bizarre dentition from Brazil. Zoological Journal of the Linnean Society 163: S109-S115.

Kellner, A.W.A., Pinheiro, A.E.P., and Campos, D.A. 2014. A New Sebecid from the Paleogene of Brazil and the Crocodyliform Radiation after the K-Pg Boundary. PLOS ONE 9: e81386. Doi: 10.1371/journal.pone.0081386
Kellner, A.W.A., Pinheiro, A.E.P., Azevedo, S.A.K., Henriques, D.D.R., Carvalho, L.B., and Oliveira, G.R. 2009. A new crocodyliform from the Alcântara Formation (Cenomanian), Cajual Island, Brazil. Zootaxa 2030: 49-58.

Krause, D.W., O'Connor, P.M., Curry Rogers, K., Sampson, S.D., Buckley, G.A, and Rogers, R.R. 2006. Late Cretaceous terrestrial vertebrates from Madagascar: implications for Latin American biogeography. Annals of the Missouri Botanical Garden 93: 178-208.

Kuhn, O. 1968. Die Vorzeitlichen Krokodile. Oeben, Krailing, 124 p.

Larsson, H.C.E., and Gado, B. 2000. A new early Cretaceous crocodyliform from Niger. Neues Jahrbuch für Geologie und Paläontologie, Abhandlungen 217: 131-141.

Larsson, H.C.E., and Sues, H-D. 2007. Cranial osteology and phylogenetic relationships of Hamadasuchus rebouli (Crocodyliformes: Mesoeucrocodylia) from the Cretaceous of Morocco. Zoological Journal of the Linnean Society 149: 533-567.

Leardi, J.M., and Pol, D. 2009. The first crocodyliform from the Chubut Group (Chubut Province, Argentina) and its phylogenetic position with in basal Mesoeucrocodylia. Cretaceous Research 30: 1376-1386.

Leardi, J.M., Fiorelli, L.E., and Gasparini, Z. 2015. Redescription and reevaluation of the taxonomical status of Microsuchus schilleri (Crocodyliformes: Mesoeucrocodylia) from the Upper Cretaceous of Neuquén, Argentina. Cretaceous Research 52: 153-166.

Levinton, J. 1988. Genetics, paleontology, and macroevolution. Cambridge University Press, Cambridge, 634 p.

Mannion, P.D., Upchurch, P., Carrano, M.T., and Barrett, P.M. 2011. Testing the effect of the rock record on diversity: a multidisciplinary approach to elucidating the generic richness of sauropodomorph dinosaurs through time. Biological Reviews 86: 157-181.

Marinho, T.S., and Carvalho, I.S. 2009. An armadillo-like sphagesaurid crocodyliform from the Late Cretaceous of Brazil. Journal of South American Earth Sciences 27: 36-41.

Marinho, T.S., lori, F.V., Carvalho, I.S., and Vasconcellos, F.M. 2013. Gondwanasuchus scabrosus gen. et sp. nov., a new terrestrial predatory crocodyliform (Mesoeucrocodylia: Baurusuchidae) from the Late Creataceous Bauru Basin of Brazil. Cretaceous Research 44: 104-111.

Martinelli, A.G., and Pais, D.F. 2008. A new baurusuchid crocodyliform (Archosauria) from the Late Cretaceous of Patagonia (Argentina). Comptes Rendus Palevol 7: 371-381.

Martinelli, A.G., Sertich, J.J.W., Garrido, A.C., and Pradeiro, A.M. 2012. A new peirosaurid from the Upper Cretaceous of Argentina: Implications for specimens referred to Peirosaurus torminni Price (Crocodyliformes: Peirosauridae). Cretaceous Research 37: 191-200.

Martinelli, A.G., and Teixeira, V.P.A. 2015. The Late Cretaceous vertebrate record from the Bauru Group in the Triângulo Mineiro, southern Brazil. Boletín Geológico y Minero 126: 129-158.

Miller, A.I. 2000. Conversations about Phanerozoic global diversity. In D. H. Erwin, and S. L. Wing (Eds.), Deep Time: Paleobiology's Perspective. Supplement to Paleobiology 26(4): 53-73.

Montefeltro, F.C., Larsson, H.C.E., and Langer, M.C. 2011. A New Baurusuchid (Crocodyliformes, Mesoeucrocodylia) from the Late Cretaceous of Brazil and the Phylogeny of Baurusuchidae. PLOS ONE 6: e21916. Doi:10.1371/journal.pone.0021916.

Montefeltro, F.C., Larsson, H.C.E., de França, M.A.G., and Langer, M.C. 2013. A new neosuchian with Asian affinities from the Jurassic of northeastern Brazil. Naturwissenschaften 100: 835-841.

Nascimento, P.M., and Zaher, H. 2010. A new species of Baurusuchus 
(Crocodyliformes, Mesoeucrocodylia) from the Upper Cretaceous of Brazil, with the first complete postcranial skeleton described for the family Baurusuchidae. Papéis Avulsos de Zoologia 50: 323-361.

Nobre, P.H., and Carvalho, I.S. 2006. Adamantinasuchus navae: A new Gondwanan Crocodylomorpha (Mesoeucrocodylia) from the Late Cretaceous of Brazil. Gondwana Research 10: 370-378.

Norell, A.M. 1992. Taxic origin and temporal diversity: the effect of phylogeny. In: M.J. Novacek, and Q.D. Wheeler (Eds.), Extinction and Phylogeny. New York, Columbia University Press, p. 89-118.

Norell, M.A., and Novacek, M.J. 1992a. Congruence between superpositional and phylogenetic patterns: comparing cladistic patterns with fossil evidence. Cladistics 8: 319-337.

Norell, M.A., and Novacek, M.J. 1992b. The fossil record and evolution: comparing cladistic and paleontologic evidence for vertebrate history. Science 255: 1690-1693.

Novas, F.E., Pais, D.F., Pol, D., Carvalho, I.S., Scanferla, A., Mones, A., and Suárez Riglos, M. 2009. Bizarre notosuchian crocodyliform with associated eggs from the Upper Cretaceous of Bolivia. Journal of Vertebrate Paleontology 29: 1316-1320.

O'Connor, P.M., Sertich, J.J.W., Stevens, N.J., Roberts. E.M., Gottfried, M.D., Hieronymus, T.L., Jinnah, Z.A., Ridgely, R., Ngasala, S.E., and Temba, J. 2010. The evolution of mammal-like crocodyliforms in the Cretaceous Period of Gondwana. Nature 466: 748751.

Ortega, F. 2004. [Historia evolutiva de los cocodrilos Mesoeucrocodylia. PhD dissertation, Universidad Autónoma de Madrid, Madrid, 350 p. Unpublished.]

Ortega, F., Buscalioni, A.D., and Gasparini, Z. 1996. Reinterpretation and new denomination of Atacisaurus crassiproratus (Middle Eocene; Issel, France) as cf. Iberosuchus (Crocodylomorpha: Metasuchia). Geobios 29: 353-364.

Ortega, F., Gasparini, Z., Buscalioni, A.D., and Calvo, J.O. 2000. A new species of Araripesuchus (Crocodylomorpha, Mesoeucrocodylia) from the Lower Cretaceous of Patagonia (Argentina). Journal of Vertebrate Paleontology 20: 57-76.

Pol, D. 2003. New remains of Sphagesaurus huenei (Crocodylomorpha: Mesoeucrocodylia) from the Late Cretaceous of Brazil. Journal of Vertebrate Paleontology 23: 817-831.

Pol, D., and Apesteguía, S. 2005. New Araripesuchus Remains from the Early Late Cretaceous (Cenomanian-Turonian) of Patagonia. American Museum Novitates 3490: 1-38.

Pol, D., and Larsson, H.C.E. 2011. $1^{\text {st }}$ Symposium on the evolution of crocodyliforms. Zoological Journal of the Linnean Society 163 : S1-S6.

Pol, D., and Powell, J.E. 2011. A new sebecid mesoeucrocodylian from the Rio Loro Formation (Palaeocene) of north-western Argentina. Zoological Journal of the Linnean Society 163: S7-S36.

Pol, D., Leardi, J.M., Lecuona, A., and Krause, M. 2012. Postcranial anatomy of Sebecus icaeorhinus (Crocodyliformes, Sebecidae) from the Eocene of Patagonia. Journal of Vertebrate Paleontology 32: 328-354.

Pol, D., Nascimento, P., Carvalho, M., Riccomini, A.B., Pires-Domingues, R.A., and Zaher, H. 2014. A new notosuchian from the Late Cretaceous of Brazil and the phylogeny of advanced notosuchians. PLoS ONE9: e93105. Doi: 10.1371/journal.pone.0093105.

Prasad, G.V.R., and de Broin, F.L. 2002. Late Cretaceous crocodile remains from Naskal (India): comparisons and biogeographic affinities. Annales de Paléontologie 82: 19-71.

Prasad, G.V.R., Verma, O., Flynn, J.J., and Goswami, A. 2013. A new Late Cretaceous vertebrate fauna from the Cauvery Basin, South India: Implications for Gondwanan paleobiogeography.
Journal of Vertebrate Paleontology 33: 1260-1268.

Price, L.I. 1945. A new reptile from the Cretaceous of Brazil. Notas Preliminares e Estudos, Servicio Geologia Mineralogia do Brasil 25: 1-8.

Price, L.I. 1950a. On a new crocodilian, Sphagesaurus, from the Cretaceous of the State of São Paulo, Brazil. Anais da Academia Brasileira de Ciências 22: 77-83.

Price, L.l. 1950b. Os crocodilideos da fauna da Formação Baurú do Cretáceo terrestre do Brasil Meridional. Anais da Academia Brasileira de Ciências 22: 473-490.

Price, L.I. 1955. Novos crocodilideos dos Arenitos da Série Bauru, Cretáceo do estado de Minas Gerais. Anais da Academia Brasileira de Ciências 27: 487-498.

Price, L.I. 1959. Sobre um crocodilideo notossuquio do Cretáceo Brasileiro. Boletim Divisão de Geolgia e Mineralogia Rio de Janeiro 118: 1-55.

Rabi, M., and Sebök, N. 2015. A revised Eurogondwana model: Late Cretaceous notosuchian crocodyliforms and other vertebrate taxa suggest the retention of episodic faunal links between Europe and Gondwana during most of the Cretaceous. Gondwana Research 28: 1197-1211.

Rasmusson Simons, E.L., and Buckley, G.A. 2009. New material of "Trematochampsa" oblita (Crocodyliformes, Trematochampsidade) from the Late Cretaceous of Madagascar. Journal of Vertebrate Paleontology 29: 599-604.

Rusconi, C. 1933. Sobre reptiles cretáceos del Uruguay (Uruguaysuchus Aznarezi [sic] n. g. n. sp.) y sus relaciones con los notosúquidos de Patagonia. Boletín del Instituto Geológico del Uruguay 19: $1-64$.

Sereno, P.C., and Larsson, H.C.E. 2009. Cretaceous Crocodyliforms from the Sahara. ZooKeys 28: 1-143.

Sereno, P.C., Sidor, C.A., Larsson, H.C.E., and Gado, B. 2003. A new notosuchian from the early Cretaceous of Niger. Journal of Vertebrate Paleontology 23: 477-482.

Sertich, J.J.W., and O'Connor, P.M. 2014. A new crocodyliform from the middle Cretaceous Galula Formation, southwestern Tanzania. Journal of Vertebrate Paleontology 34: 576-596.

Simons, E.L.R, and Buckley, G.A. 2009. New Material of "Trematochampsa" oblita (Crocodyliformes, Trematochampsidae) from the Late Cretaceous of Madagascar. Journal of Vertebrate Paleontology 29: 599-604.

Soto, M., Pol, D., and Perea, D. 2011. A new specimen of Uruguaysuchus aznarezi (Crocodyliformes: Notosuchia) from the middle Cretaceous of Uruguay and its phylogenetic relationships. Zoological Journal of the Linnean Society 163: S173-S198.

Stromer, E. 1914. Ergebnisse der Forschungsreisen Prof. E. Stromers in den Wüsten Ägyptens. II Wirbeltier-Reste der BaharîjeStufe (unterstes Cenoman). 1. Einleitung und 2. Libycosuchus. Abhandlungen der Königlich Bayerischen Akademie der Wissenschaften 27: 1-16.

Turner, A.H. 2006. Osteology and phylogeny of a new species of Araripesuchus (Crocodyliformes: Mesoeucrocodylia) from the Late Cretaceous of Madagascar. Historical Biology 18: 255-369.

Turner, A., and Sertich, J.J.W. 2010. Phylogenetic history of Simosuchus clarki (Crocodyliformes: Notosuchia) from the Late Cretaceous of Madagascar. Journal of Vertebrate Paleontology, Special Issue, Memoir 10: 177-236.

Wilson, J.A., Malkani, M.S., and Gingerich, P.D. 2001. New crocodyliform (Reptilia, Mesoeucrocodylia) from the Upper Cretaceous Pab Formation of Vitakri, Balochistan (Pakistan). Contributions from the Museum of Paleontology University of Michigan 30: 321-336. 
Woodward, A.S. 1896. On two mesozoic crocodilians, Notosuchus (genus novum) and Cynodontosuchus (gen. nov.) from the red sandstones of Territory of Neuquén (Argentina). Anales del Museo de La Plata, Serie Paleontológica 4: 1-20.

Wu, X.-C., and Sues, H.-D. 1996. Anatomy and phylogenetic relationships of Chimaeresuchus paradoxus, an unusual crocodyliform reptile from the Lower Cretaceous of Hubei, China. Journal of Vertebrate Paleontology 16: 688-702.

Wu, X.-C., Sues, H.-D., and Sun, A. 1995. A plant-eating crocodyliform reptile from the Cretaceous of China. Nature 376: 678680.

Recibido: 10 de junio de 2015

Aceptado: 21 de noviembre de 2015 